\title{
Preoperative evaluation of the cardiac patient for noncardiac surgery
}

Paul G. Barash MD

Extrapolation of demographic data suggests that more than $25 \%$ of the 25 million patients anaesthetized annually in the United States are at risk or have clinically significant cardiovascular disease.' Although much attention has focused on management of the patient with cardiac disease undergoing open heart surgery, the cardiac patient scheduled for a non-cardiac surgical procedure may represent a more severe management challenge to the anesthetist. In contrast to the open heart surgical patient, these patients usually do not have as extensive a workup directed at the cardiovascular system; are not as well medically prepared; do not have similar intra- and postoperative resources available; and finally their postoperative care is not focused on the cardiovascular system. Perhaps more importantly, unlike the open heart surgical patient, the cardiac patient undergoing a noncardiac operation cannot expect immediate improvement in cardiac performance postoperatively. In fact these patients may actually have a decline in cardiovascular performance.

This review will emphasize pre- and postoperative evaluation of patients with cardiovascular disease. The areas to be covered include: (1) hypertension, (2) congestive heart failure $(\mathrm{CHF}),(3)$ coronary artery disease (CAD), and (4) postoperative surveillance for myocardial infraction (MI).

It is important to evaluate, diagnose, and perform risk stratification, in that order. Too often during the early stages of the evaluation process, risk is assigned before a diagnosis has been confirmed. The goal is to acquire the most diagnostic information with the fewest tests, and the least risk, discomfort and expense to the patient. Ordering of diagnostic tests is based upon the probability of confirming the cardiovascular diagnosis. Methods to reduce risk can then be evaluated and a plan of perioperative management developed.

\section{Hypertension}

Of the cardiovascular diseases, hypertension is the most prevalent, affecting more than 59 million patients. Forty per cent of patients who are aware that they have hypertension are either untreated or inadequately managed with pharmacological therapy. ${ }^{2}$ Therefore, a large percentage of patients with hypertension can present for preoperative anaesthesia evaluation with poor control of their disease. Hypertension is also an important marker as a risk factor for congestive heart failure and ischaemic heart disease. Hypertension results in: (1) an increased systemic vascular resistance, (2) decreased intravascular volume, (3) exaggerated pressor response, and (4) oedema. For patients greater than 18 years old, hypertension is defined as BP $>140 / 90 \mathrm{mmHg} .{ }^{3}$ Most hypertension is essential; in selected patients as indicated by history, physical examination and baseline laboratory data, a more extensive workup may reveal a primary and treatable cause of hypertension (e.g., renal artery stenosis). ${ }^{4}$

Commonly, hypertension on admission to the hospital is regarded as a "normal" response to the stress of hospital admission. However, this group of patients may represent an untreated or inadequately managed subset of hypertensive patients. A study examining this problem revealed that these patients generated the highest mean arterial BP (MAP) in response to laryngoscopy and intubation. ${ }^{5}$ In addition, myocardial ischaemia was observed and $75 \%$ of the patients in this group required vasodilator therapy. In contrast those patients with normal admission BP, or adequately treated hypertension, had an uneventful periinduction course.

In the perioperative period uncontrolled or poorly controlled hypertension is associated with an increased incidence of ischaemia, myocardial infarction, dysrhythmias and stroke. ${ }^{6}$ Adequate preoperative treatment is associated with a reduced incidence of serious cardiovascular complications. A controlled study demonstrated that hypertensive patients who have long-term pharmacologic treatment accrue a physiologic benefit. ${ }^{7}$ Thirteen patients treated with the beta blocker metoprolol for seven years had: (1) normalization of haemodynamics, (2) reversal of left ventricular (LV) hypertrophy, (3) normalization of LV wall stress, (4) preserved LV systolic function, (5) normalization of renal vascular resistance, and (6) decreased albuminuria. These changes were not observed in the untreated control population. Anti-hypertensive therapy has a salutary effect with regard to the anaesthetic

From the Department of Anesthesiology, Yale University School of Medicine, New Haven, CT 06510. 
management of hypertensive patients. ${ }^{8}$ Even a single dose of beta antagonist administered $90 \mathrm{~min}$ before induction of anaesthesia results in a significant reduction in the incidence of intraoperative hypertension and myocardial ischaemia, as well as postoperative cardiac morbidity. ${ }^{9}$

Current consensus when managing hypertensive patients suggests continuation of antihypertensive maintenance of drug therapy throughout the perioperative period; this includes maintenance of the patient's routine anti-hypertensive medication with the anaesthesia premedication. Although the beneficial effects of pharmacologic treatment have been emphasized, it is important to remember these compounds have side-effects which may have a significant impact on anaesthetic management.

\section{Congestive heart failure}

The impact of congestive heart failure (CHF) on perioperative morbidity and mortality is often minimized. Currently 2.3 million Americans have CHF with 400,000 added each year. The incidence of $\mathrm{CHF}$ doubles with each decade between $45-75$ yr. It is the number one diagnostic related group (DRG) diagnosis. The mortality rate of $\mathrm{CHF}$ is between $15-60 \%$ with 200,000 deaths each year. Various diagnostic schema have been used to clinically define CHF. ${ }^{10}$ The Boston criteria relies on three categories: history, physical examination and chest radiograph. In contrast the Framingham criteria use major clinical factors (e.g., rales, cardiomegaly, etc.) and minor factors (dyspnoea on exertion, decreased vital capacity, etc.). The physiological hallmarks of the disease include: (1) decreased cardiac output, (2) increased ventricular filling pressures, (3) increased systemic vascular resistance, and (4) acidosis. Dysrhythmias are an important component of the disease process and its associated mortality. "Therapy is directed at reducing ventricular filling pressures as well as improving cardiac output. The angiotensin converting enzyme (ACE) inhibitors are a marked therapeutic advance and currently serve as a foundation for treatment. ${ }^{12,13}$ Patients receiving ACE inhibitors may sustain intraoperative hypotension. This class of drugs blocks angiotensin II formation secondary to compensatory renin release. If the hypotension is thought to be due to this mechanism, treatment consists of volume expansion.

\section{Coronary artery disease}

Coronary artery disease (CAD) affects nearly seven million patients per year and is associated with the highest morbidity and mortality rates of the cardiovascular diseases. Certain centres have shown the importance of protocols involving elaborate preoperative testing is necessary (including cardiac catheterization), while others have shown a more conservative approach, with selective diagnostic testing, is equally beneficial in terms of outcome. ${ }^{13-16}$

Obtaining an extensive history is the starting point of the diagnostic decision tree. ${ }^{17}$ The history should allow the anaesthetist to state: (1) the patient is asymptomatic with little likelihood of disease, (2) there is a significant possibility that CAD is present, or (3) the patient definitely has CAD. The physical examination is then used to diagnose and document the state of impairment of core organ reserve secondary to CAD. Unfortunately, data from the physical examination is often too insensitive to enable the clinician to confirm the presence of CAD. ${ }^{18}$

Of the usual preoperative tests, the chest radiograph and ECG may occasionally yield diagnostic information. The chest radiograph is useful if it shows such positive findings as: cardiomegaly, interstitial oedema, and calcification or aneurysm of arteries, etc. The 12-lead resting ECG has limited diagnostic value since the resting ECG is normal in $25-50 \%$ of patients with CAD, is nondiagnostic in an additional $25 \%$ of patients with conduction defects (e.g., Wolf Parkinson White) and is non-diagnostic. However, in a select group of patients the resting 12-lead ECG can amplify the findings of the history and physical examination. ST segment waveform changes consistent with an old MI are highly suggestive of the presence of CAD. Positive "u" waves on the resting ECG are associated with left main coronary artery disease. ${ }^{19}$

Once the above data have been obtained, additional supplemental diagnostic tests may be required to confirm the presence or absence of CAD. These tests may be performed: (1) at rest or (2) during exercise (stress test). It is this portion of the diagnostic workup for which there appears to be limited consensus from the literature. In examining non-invasive cardio-diagnostic data the following terms are important to understand fully the diagnostic capabilities of an individual test: sensitivity and specificity (as compared to a "gold standard" such as the coronary angiogram) (Figure 1). ${ }^{20}$ After the operating characteristics of the test are known, a probability estimate for CAD in a given patient can be derived using Bayes' theorem.

Bayes' theorem allows the clinician to calculate (before ordering a test) the probability of the presence of disease (e.g., CAD) if the diagnostic test is positive. ${ }^{21}$ To compute the post-test probability of the presence of a disease, the following must be known:

1 the prevalence of the disease in a group of patients similar to the one under study;

2 the sensitivity and specificity of the diagnostic test.

If there is a low probability of disease, despite a positive test result, then the additional test should not be ordered. Conversely, if there is a high probability of the 


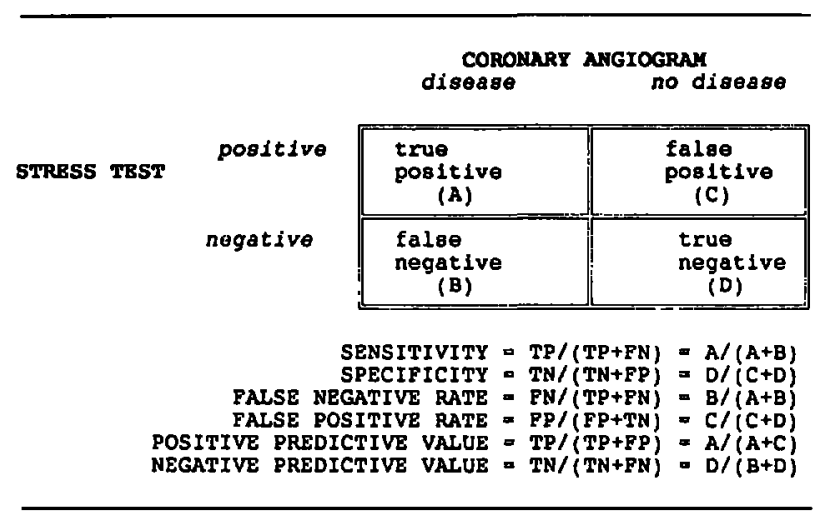

FGURE 1 Typical display of test data from which are derived definitions of sensitivity, specificity, false negative rate, false positive rate, positive predictive value and negative predictive value. ( $T P=$ true positive, $T N=$ true negative, $F P=$ false positive, $\mathrm{FN}=$ false negative, $\mathrm{PPV}=$ positive predictive value, $\mathrm{NPV}=$ negative predictive value)

presence of disease with a positive test result, then it is appropriate to use it as part of the diagnostic work-up.

If the preliminary diagnostic evaluation has not confirmed the presence of CAD, the next step is the stress testing. An ECG stress test progressively increases myocardial work with graded exercise. Indicators of ischaemia include development of angina, ECG changes (e.g., segment deviation, the appearance of dysrhythmias, conduction defects) and haemodynamic abnormalities. ' The ECG exercise test is of limited value as a screening device in an asymptomatic population. Finally, ECG stress testing data should be viewed with caution since sensitivity and specificity will be different in men and women.

Stress testing can also be performed with a radionuclear imaging protocol. Exercise radionuclear tests are most appropriate when a preexisting ECG abnormality limits interpretation or when the result of the ECG stress test is ambiguous or yields an unexpected result. Both thallium 201 (cold spor) and technetium $99 \mathrm{~m}$ (hot spot) have been used as the isotopes. ${ }^{1}$ At rest, severe coronary stenosis $(<90 \%)$ must be present for the thallium test to be positive. "Cold" spots or perfusion defects appear 30$60 \mathrm{~min}$ post-radioisotope injection. A period of redistribution occurs at 2-4 hr. A repeat image is ordered at four hours. Defects in the one-hour and four-hour tests indicate infarcted tissue. Cold spots that are present at one hour but disappear at four hours (reversible) indicate areas of myocardial ischaemia.

Although thallium can be used as part of, or instead of, an ECG stress test, it is being used in conjunction with intravenous dipyridamole. ${ }^{22}$ Dipyridamole is a coronary vasodilator and is administered to patients who cannot perform exercise on a treadmill due to peripheral vascular disease. The dipyridamole thallium test (DPT) not only supplies important diagnostic information, but also has been shown to have significant prognostic capabilities in selected subsets of surgical patients. ${ }^{23}$ However, it is of limited value for single vessel coronary disease (left main or right coronary artery) or proximal triple vessel disease. ${ }^{24}$ More recent studies suggest that improvements in protocol (repeat thallium injection) and quantitative measurements of redistribution will improve the predictive value of the test. ${ }^{25.26}$

Another form of stress test is daily activity. Ambulatory electrocardiography (AECG), by use of a Holter monitor type device, allows ECG detection of symptomatic ischaemic events (angina) as well those that are clinically silent (no angina). ${ }^{27}$ Advocates of this technology claim it is more useful than current diagnostic tests both for diagnosis and risk assessment. ${ }^{28}$ However, others state that the exercise ECG supplies similar information in a more quantifiable fashion and that the only indication for use of AECG is to detect episodes of coronary vasospasm. ${ }^{29}$ An American Heart Association Task Force evaluating this technology stated that more data are required before AECG becomes an acceptable part of routine diagnostic test methods for CAD. ${ }^{30}$

Various imaging techniques, such as radionuclear scans, echocardiography and angiography, can definitively establish the presence of CAD and also document the level of ventricular performance. Recent reviews have highlighted the importance of such diagnostic imaging in the perioperative period. ${ }^{1,31}$ Radionuclear tests can evaluate myocardial perfusion, viability and ventricular function. Although echocardiography is useful as an intraoperative monitor (e.g., transoesophageal echocardiography), ultrasound is becoming an important component of the CV diagnostic workup as well. This modality is being adapted to stress testing as well as diagnosis of valvular and congenital heart disease. Finally, coronary angiography is used as the last step in the decision tree to define the presence of CAD.

Using this guided approach to the ordering of cardiodiagnostic tests, an algorithm can be developed to aid the clinician (Figure 2).

Assigning cardiac risk in the perioperative period After a cardiovascular diagnosis has been established, it is helpful to quantitate the risk of an adverse cardiac event in the perioperative period. Assigning risk depends on a number of factors including the cardiovascular lesion. Eagle and Boucher suggest that patient subsets with expected perioperative cardiovascular event rate greater that $15 \%$ should be more extensively tested. Those subsets who exhibit a morbidity rate less than $5 \%$ do not require further screening. ${ }^{32}$

The two preoperative factors that appear to increase 


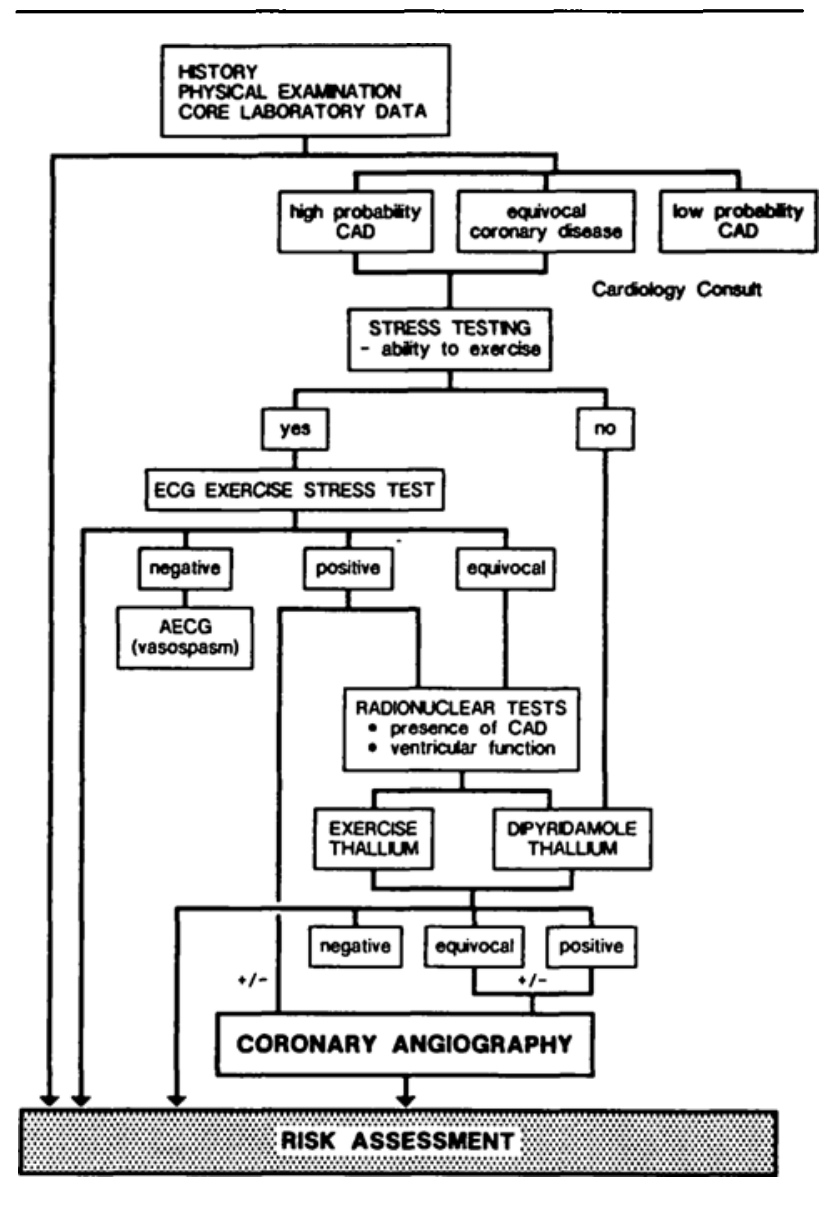

FGURE 2 Algorithm for the use of cardiac diagnostic tests. AECG $=$ ambulatory ECG. Sec text for details. Reproduced with permission. Barash PG (Ed.): Clinical Anesthesia Update Series. Pennsylvania: J.B. Lippincott Publisher 1990

risk for postoperative cardiac morbidity are MI within six months and current $\mathrm{CHF}{ }^{\prime}$ All other preoperative factors including age, angina, previous CHF, hypertension, diabetes, etc., may be of importance in selected patient subsets. A postoperative $\mathrm{MI}$ is a lethal lesion with a $>50 \%$ mortality rate. In the Cardiac Risk Index, the factor given the greatest weight is the presence of an S3 gallop, usually associated with CHF. ${ }^{33}$

Recent investigations suggest that patients with preoperative ischaemia (silent or anginal) are a greater risk for postoperative complications. In a study of vascular surgical patients, $38 \%$ of those who had a postoperative cardiac event had preoperative ischaemia. ${ }^{34}$ In contrast only $1 \%$ of patients without preoperative ischaemia sustained postoperative cardiac morbidity. Relevant to this area is a canine study which reports that brief periods of myocardial ischaemia, which individually do not cause necrosis of the myocardium, may have a cumulative effect and cause a significant area of necrosis (infarction). ${ }^{35}$ The importance of these findings may be gleaned from a study of patients undergoing peripheral vascular procedures. Postoperative myocardial infarction was directly related to the number and length of ischaemic episodes and total duration of ischaemia. ${ }^{36}$

Appropriate sequencing of diagnostic tests not only improves sensitivity and specificity for the diagnosis of CAD, but also improves risk stratification. ${ }^{37.38}$ From the preceding discussion it is apparent that patients can be divided into three risk groups: low, intermediate and high. In a group of patients $(n=200)$ undergoing major vascular surgery, Eagle et al. described a low-risk group who had no clinical variables (e.g., angina, diabetes, $Q$ waves on ECG, etc.) for the presence of CAD. ${ }^{36}$ Only $3 \%$ (2/64) sustained postoperative ischaemia. In contrast, in the high-risk group (three or more clinical factors), 50\% (10/20) had clinically significant postoperative cardiac morbidity. A majority of the patients $(n=116)$ had one or two clinical variables present and were assigned to the intermediate-risk group. On the basis of the presence or absence of thallium redistribution on their dipyridamolethallium test, this group could be further subdivided into low- $(n=64)$ and high-risk $(n=54)$ subsets. Only $3 \%$ (2/64) patients without thallium redistribution had a postoperative cardiac event. In comparison, those with thallium redistribution had $30 \%$ (16/54) postoperative cardiac event rate. The authors concluded that preoperative DPT helps stratify those patients who were determined to be at intermediate risk by clinical evaluation. Further, and perhaps more important, for nearly half the patients in their series, clinical information alone predicted risk (high- and low-risk groups) and the use of the DPT was unnecessary.

\section{Postoperative MI surveillance}

Postoperative $\mathrm{Ml}$ is a disease which carries a poor prognosis ( $>50 \%$ mortality rate). On a theoretical basis, earlier recognition and initiation of therapy may result in a decreased mortality rate. Various protocols have been promulgated for the "Rule Out MI" workup (ROMI). These range from admission to the coronary care unit with extensive testing to observation on the ward. Charison et al. evaluated different ROMI surveillance strategies for the cardiac patient who is asymptomatic postoperatively. ${ }^{39}$ They found that obtaining an ECG on the day of surgery and postoperative days one and two yielded the largest number of patients who subsequently developed an MI. Their data suggest that more traditional protocols used to document an $\mathrm{Ml}$ would apparently miss $58 \%$ of patients who sustained an $\mathrm{MI}$ or ischaemia. In a retrospective study evaluating asymptomatic patients in the PACU, McCloskey et al. reported that unless haemodynamically unstable or requiring intravenous anti-dysrhythmia ther- 
apy, the ROMI workup could be safely performed on the ward. ${ }^{40}$ More stringent CCU admission criteria would result in significant cost-saving without compromising patient outcome.

\section{Summary}

In summary, obtaining a comprehensive patient history is a critical part of the diagnostic and risk stratification process of the patient with cardiac disease undergoing non-cardiac surgery. Many of the factors associated with perioperative cardiac morbidity are treatable and early and aggressive management appears to have beneficial effects on morbidity and mortality rates. ${ }^{41}$

(This review is based in part on: Barash PG. Preoperative evaluation of the cardiac patient for noncardiac surgery. Clinical Anesthesia: Updates 1990; 1: 1-10.)

\section{References}

1 Mangano DT. Perioperative cardiac morbidity. Anesthesiology 1990; 72: 153-84.

2 Ibrahim $M$, Chobanian AV, Horan M, Roccella EJ. Hypertension prevalance and the status of awareness, treatment and control in the United States. Hypertension 1985; 7: 457-68.

3 Dustan HP, Chobanian AV, Falkner et al. The 1984 report of the joint national committec on detection, evaluation, and treatment of high blood pressure. Arch Int Med 1984; 144: 1045-57.

4 Kaplan NM. Systemic hypertension: mechanisms and diagnosis. In: Braunwald E. (Ed.). Heart Disease. Philadelphia: WB Saunders, 1988; 819-61.

5 Bedford RF, Feinstein B. Hospital admission blood pressure, a predictor for hypertension following endotracheal intubation. Anesth Analg 1980; 59: 357-70.

6 Asiddao CB, Donegan JH, Whitsell RC, Kalbfleish $J H$. Factors associated with perioperative complications during carotid endarterectomy. Anesth Analg 1982; 61: 631-7.

7 Hartford M, Wendelhag I, Berglund G, Wallentin I, Ljungman $S$. Cardiovascular and renal effects of longterm antihypertensive treatment. JAMA 1988; 259: 25537.

8 Prys-Roberts $C$, Meloche R, Foex $P$. Studies of anaesthesia in relation to hypertension: 1 . cardiovascular responses to treated and untreated patients. Br J Anacsth 1971; 43: 122-37.

9 Stone JG, Foex $P$, Scar JW, Johnson LL, Khambatta HJ, Triner $L$. Myocardial ischemia in untrcated hypertensive patients: effect of a single small dose of a beta- adrenergic blocking agent. Anesthesiology 1988; 68: 495-500.

10 Marantz PR, Tobin JN, Wassertheil-Smollers $S$ et al. The relationship between left ventricular systolic function and congestive heart failure diagnosed by clinical critcria Circulation 1988; 77: 607-12.

11 Bigger Jr JT. Why patients with congestivc heart failure die: arrhythmias and sudden death. Circulation 1987: 75 (suppl IV): 28-35.

12 Packer M, Lee WH, Kessler PD, Gottlieb SS, Bernstein JL, Kukin $M L$. Role of ncurohormonal mechanism in determining survival in patients with severe congestive heart failure. Circulation 1987; 75 (suppl IV): 80-92.

13 Massie BM. Conway $M$. Survival of patients with congenital heart failurc: past, present, and future prospects. Circulation 1987; 75 (suppl 1V): 11-9.

14 Hertzer NR, Bevan EG, Young JR et al. Coronary artery disease in peripheral vascular patients. A classification of 1000 coronary angiograms and results of surgical management. Ann Surg 1984; 199: 223-33.

15 Brown OW, Hollier LH, Pairolero PC, Kzmier FJ, McCready RA. Abdominal aortic aneurysm and coronary artery disease. Arch Surg 1981; 116: 1484-8.

16 Perry MO, Calcagno D. Abdominal aortic ancurysm surgery: the basic evaluation of cardiac risk. Ann Surg 1988; 208: 738-42.

17 Shub C. Stable angina pectoris: 1. Clinical patterns. Mayo Clin Proc 1990; 64: 233-42.

18 Shub $C$. Stable angina pectoris: 2. Cardiac evaluation and diagnostic testing. Mayo Clin Proc 1990; 65: 243-55.

19 Gerson $M C, M c H e n r y P L$. Resting $U$ wave inversion as a marker of stenosis of the left anterior descending coronary artery. Am J Med 1980; 69: 545-50.

20 Gibson RS, Beller CA. Should exercise electrocardiography testing be replaced by radioisotope methods? In: Rahimtoola SH (Ed.). Controversies in Coronary Artery Disease. Philadelphia, FA Davis, 1983: 1-31.

21 Shulman $P$. Bayes' theorem - a review. Cardiol Clin 1984; 2: 319-28.

22 Younis $L T$, Chaitman BR. Update on intravenous dipyridamole cardiac imaging in the assessment of ischemic heart disease. Clin Cardiol 1990; 13: 3-10.

23 McPhail NV, Ruddy TD, Calvin JE, Davies RA, Barber $G G$. A comparison of dipyridamole-thallium imaging and exercise testing in prediction of postoperative cardiac complications in patients requiring arterial reconstruction. J Vasc Surg 1989; 10: 51-6.

24 Marwick TH, Underwood DA. Dipyridamole thallium imaging may not be a reliable screcning test for coronary artery disease in patients undergoing vascular surgery. Clin Cardiol 1990; 13: 14-8.

25 Dilsizian V, Rocco TP, Freedman NM, Leon MB, Bonow 
$R$. Enhanced detection of ischemic but viable myocardium by the reinjection of thallium after stress redistribution imaging. N Engl J Med 1990; 323: 141-6.

26 Levinson JR, Boucher CA, Colley CM, Guiney TE, Strauss $H W$, Eagle $K A$. Usefullness of semiquantitative analysis of dipyridamole thallium-20I redistribution for improving risk stratifications before vascular surgery. Am J Cardiol 1990; 66: 506-10.

27 Parmely $W W$. Prevalence and clinical significance of silent myocardial ischemia. Circulation 1989: 80 (suppl IV): 68-73.

28 Knight AA, Hollenberg $M$, London MJ et al. Perioperative myocardial ischemia: importance of preoperative ischemia pattern. Anesthesiology 1988; 68: 681-8.

29 Epstein SE, Quyymi AA, Bonow RO. Current concepts myocardial ischemia - silent or symptomatic? N Engl J Med 1988; 318: 1038-43.

30 Knoebel SE, Crawford MH, Donn MI et al. Guidelines for ambulatory clectrocardiography. Circulation 1989; 79 : 206-15.

31 Cahalan MK, Litt L, Botvinick EH, Schiller NB. Advances in noninvasive cardiovascular imaging: implications for the anesthesiologist. Anesthesiology 1987: 66: 356-72.

32 Eagle KA, Boucher $C A$. Cardiac risk of noncardiac surgery. N Engl J Med 1989; 32I: 1330-2.

33 Goldman L, Caldera DL, Nussbaum SR et al. Multifactorial index of cardiac risk in noncardiac surgical procedures. N Engl J Med 1977; 297: 845-50.

34 Raby KE, Goldman L, Creager MA et al. Correlation between perioperative ischemia and major cardiac events after peripheral vascular surgery. N Engl J Med 1989; 321: 1296-300.

35 Geft IL, Fishbein MC, Ninomiya K et al. Intermittent bricf periods of ischemia have a cumulative effect and may cause myocardial necrosis. Circulation 1982; 66: 1150-3.

36 Pasternack PF, Grossi EA, Baumann FG et al. The value of silent ischemia monitoring in the prediction of perioperative myocardial infarction in patients undergoing peripheral vascular surgery. J Vasc Surg 1989; 10: 617-25.

37 Epstein SE. Implications of probability analysis on the strategy used for non-invasive detection of coronary artery disease. Am J Card 1980; 46: 491-9.

38 Eagle KA, Coley CM, Newell JB et al. Combining clinical and thallium data optimizes preoperative assessment of cardiac risk beforc major vascular surgery. Ann Int Med 1989; 110: 859-66.

39 Charison ME, MacKenzie CR, Ales KL, Gold JP, Fairclough Jr G, Shires $C T$. Surveillance for postoperative myocardial infarction after non-cardiac operations. Surg Gynecol Obstet 1988; 167: 407-14.
40 McCloskey $G$, Hines $R$, Barash $P$. Is ICU admission necessary for postoperative ROMI workup? (Abstract). Anesthesiology 1989; 71: A954.

41 Rao $T K$, Jacobs $K H$, El-Etr AA. Reinfarction following anesthesia in patients with myocardial infarction. Anesthesiology 1983; 59: 499-505. 


\section{Évaluation pré- opératoire du patient cardiaque en vue d'une chirurgie non-cardiaque Paul G. Barash мо}

L'extrapolation des données démographiques suggère que plus de $25 \%$ des 25 millions de patients anesthésiés annuellement aux États-Unis sont à risque ou font preuve cliniquement d'une maladie cardio-vasculaire significative. ${ }^{1}$ Même si l'on a porté beaucoup d'attention sur la conduite à tenir chez les patients avec maladie cardiaque qui doivent subir une chirurgie cardiaque, les patients cardiaques programmés pour une chirurgie non-cardiaque peuveut offrir un défi plus important pour l'anesthésiste. Si on les compare aux patients soumis à une chirurgie cardiaque, ces patients habituellement n'ont pas une évaluation médicale du système cardio-vasculaire aussi poussée ; n'ont pas une préparation médicale aussi soigneuse; on ne leur offre pas des ressources intra- et post-opératoires de même calibre; et finalement leurs soins post-opératoires ne sont pas orientés vers le système cardio-vasculaire. Chose encore plus importante, comparativement aux patients soumis à une chirurgie cardiaque, le malade qui subit une chirurgie non-cardiaque ne peut pas s'attendre à avoir une amélioration de sa performance cardiaque dans la période post-opératoire. De fait, ces patients peuvent en fait avoir une dégradation de leur performance cardio-vasculaire.

Cette revue va mettre l'accent sur l'évaluation pré- ou post-opératoire des patients avec maladies cardio-vasculaires. Les champs à couvrir comprennent : 1) l'hypertension ; 2) l'insuffisance cardiaque congestive ; 3) la maladie coronarienne (MC); et 4 ) la surveillance postoperatoire pour l'infarctus du myocarde (IM).

Il devient important d'évaluer, de diagnostiquer, et d'établir une stratification du risque, dans l'ordre mentionné. Il arrive trop souvent durant les stages initiaux de l'évaluation, que le risque soit assigné avant que l'on ait fait un diagnostic. Le but est d'obtenir le plus d'informations diagnostiques avec le moins d'épreuves, aux moindres risques, coûts, et inconfort pour le patient. La demande d'épreuves diagnostiques se base sur la probabilité de confirmer le diagnostic cardio-vasculaire. Les méthodes qui peuvent réduire les risques seront ensuite évaluées et on développera par la suite un plan de conduite péri-opératoire.

\section{Hypertension}

De toutes les maladies cardio-vasculaires, l'hypertension a la prévalence la plus élevée, puisqu'elle affecte 59 million de patients. Quarante pour cent des patients conscients d'être porteurs de cette maladie sont soit non traités ou mal soignés avec la thérapie pharmacologique. ${ }^{2}$ Dès lors un grand pourcentage des patients avec hypertension peuvent se présenter lors de l'évaluation préanesthésique avec un mauvais contrôle de leur maladie. L'hypertension est aussi un facteur de risque important d'insuffisance cardiaque congestive et de maladie cardiaque ischémique. L'hypertension produit : 1) une augmentation de la résistance vasculaire systémique, 2) une diminution du volume intra-vasculaire, 3) une réponse pressive et exagérée et 4) de l'œdème. Chez les patients âgés de plus de 18 ans, l'hypertension est définie comme une pression artérielle supérieure à $140 / 90 \mathrm{mmHg} .{ }^{3}$ Elle est surtout essentielle : dans un certain nombre de patients l'histoire clinique, l'examen physique et les épreuves de laboratoire de base peuvent orienter vers une évaluation plus extensive qui pourra démontrer une cause primaire de l'hypertension amenable au traitement (e.g., sténose de l'artère rénale). ${ }^{4}$

De façon courante, l'hypertension à l'admission à l'hôpital est considérée comme une réponse normale au stress de l'admission. Cependant, ce groupe de patients peut représenter un sous-groupe d'hypertendus nontraités ou mal soignés. Une étude a évalué ce problème et a revélé que ces patients obtenaient la pression artérielle moyenne la plus élevée en réponse à la laryngoscopie et à l'intubation. De plus, on a observé de l'ischémie myocardique, et $75 \%$ des patients de ce groupe ont eu besoin de thérapie aux vasodilatateurs. Lorsqu'on les compare à des patients avec pression artérielle normale à l'admission, ou chez lesquels l'hypertension est traitée adéquatement, ces derniers avaient une induction sans problème.

L'hypertension non-contrôlée ou mal contrôlée pendant la période péri-opératoire s'associe à une incidence élevée d'ischémie, d'infarctus du myocarde, de dysrythmies et d'accidents cérébro-vasculaire. ${ }^{6}$ Un traitement pré-opératoire adéquat va être associé à une diminution de 
l'incidence de complications cardio-vasculaires importantes. Une étude contrôlée a montré que les patients hypertendus qui ont eu un traitement pharmacologique à long terme en récupèrent des bénéfices physioliogiques.? Treize patients traités avec le métoprolol (un $\beta$-bloqueur) pendant sept ans avait 1) une normalisation de l'hémodynamique, 2) une régression de l'hypertrophie ventriculaire gauche, 3) une normalisation de la tension murale du ventricule gauche, 4) une préservation de la fonction systolique ventriculaire gauche, 5) une normalisation de la résistance vasculaire rénale et 6) une diminution de l'albuminurie. Ces changements n'ont pas été observés dans la population contrôle non-traitée. La thérapie anti-hypertensive a des effets salutaires pour la conduite anesthésique des patients hypertendus. ${ }^{8}$ Même une dose unique d'antagonistes bêta donnée 90 minutes avant l'induction de l'anesthésie amène une diminution significative de l'incidence d'hypertension et d'ischémie myocardique per-opératoire, et aussi de morbidité cardiaque post-opératoire. ${ }^{9}$

Le consensus actuel sur le traitement des patients hypertendus suggère de maintenir la thérapie médicamenteuse de l'hypertension pendant toute la période périopératoire; ceci comprend le maintien de la médication anti-hypertensive habituelle du patient en plus de la prémédication anesthésique. Même si on a mis l'accent sur les effets bénéfiques du traitement pharmacologique, il est important de se rappeler que ces substances ont des effets secondaires qui peuvent avoir un impact important sur la conduite de l'anesthésie.

\section{Insuffisance cardiaque congestive}

L'impact de l'insuffisance cardiaque congestive sur la morbidité et la mortalité péri-opératoire est souvent minimisé. Actuellement il y a 2,3 million d'Américains porteurs de maladie cardiaque congestive et 400000 s'ajoutent à tous les ans. L'incidence de maladie cardiaque congestive double pour chaque décade entre 45 et 75 ans. Elle constitue le plus important des diagnostics dans les groupes diagnostiques (DRG). La mortalité reliée a l'insuffisance cardiaque congestive se situe entre 15 et $60 \%$ avec 200000 décès par année. De nombreux tableaux diagnostiques ont servi à définir sur une base clinique l'insuffisance cardiaque congestive. ${ }^{10}$ Les critères de Boston s'appuient sur trois catégories : I'histoire, l'examen physique et la radiographie pulmonaire. Par contre les critères de Framingham utilisent des facteurs cliniques majeurs (e.g., les râles, la cardiomégalie, etc.) et des facteurs mineurs (dyspnée à l'effort, diminution de la capacité vitale, etc.). Les traits physiologiques importants de la maladie comprennent : 1) diminution du débit cardiaque, 2) augmentation des pressions de remplissage ventriculaire, 3) augmentation de la résistance vasculaire systémique, 4) l'acidose. Les dysrythmies constituent une composante importante de la maladie et de la mortalité associée. ${ }^{11} \mathrm{La}$ thérapie est dirigée vers la diminution des pressions de remplissage ventriculaire et vers l'amélioration du débit cardiaque. Les inhibiteurs des enzymes de conversion de l'angiotensine constituent un progrès thérapeutique important et sont actuellement la pierre angulaire du traitement. ${ }^{12,13}$ Les patients qui reçoivent des inhibiteurs de l'enzyme de conversion peuvent faire preuve d'hypotension intra-opératoire. Cette classe de médicaments bloque la formation de l'angiotensine II qui survient à la suite de libération de la rénine. Si l'hypotension semble due à ce mécanisme, l'expansion volémique en constitue le traitement.

\section{Maladie coronarienne}

La maladie coronarienne touche environ sept million de personnes par année et présente la morbidité et la mortalité les plus élevées parmi les maladies cardiovasculaires. Certains centres ont montré l'importance de protocoles qui impliquent une évaluation pré-opératoire élaborée (incluant la cathétérisation cardiaque), alors que d'autres ont montré, de leur côté, que des approches plus conservatrices avec des épreuves diagnostiques choisies, sont aussi bénéfiques en terme d'issue. ${ }^{13-16}$

L'obtention d'une histoire clinique détaillee constitue le point de départ de l'arbre de décision diagnostique. ${ }^{17}$ Cette histoire devrait permettre à l' anesthésiste de définir : 1) si le patient est asymptomatique avec peu de probabilité d'avoir la maladie, 2) s'il y a une possibilité importante que la maladie coronarienne soit présente ou 3) que le patient a de façon définitive une maladie coronarienne. L'examen physique est ensuite employé pour diagnostiquer et documenter l'atteinte des réserves secondaire à la maladie coronarienne. Malheureusement, les données tirées de l'examen physique sont souvent trop peu sensibles pour permettre aux cliniciens de confirmer la présence de maladie coronarienne. ${ }^{18}$

Parmi les épreuves pré-opératoires courantes, la radiographie pulmonaire et l'ECG peuvent occasionnellement donner certaines informations diagnostiques. La radiographie pulmonaire sera utile si elle montre des trouvailles positives telles que : cardiomégalie, œdème interstitiel, calcification ou anévrysme artériel, etc. L'électro-cardiogramme à 12 dérivations pris au repos a une valeur diagnostique limitée puisque l'électro-cardiogramme au repos est normal chez 25 à $50 \%$ des patients avec maladie coronarienne et $n$ 'apporte pas d'élément diagnostic chez un autre $25 \%$ des patients avec problèmes de conduction (e.g., Wolfe-Parkinson-White). Cependant, dans un groupe choisi de patients, l'electrocardio- 


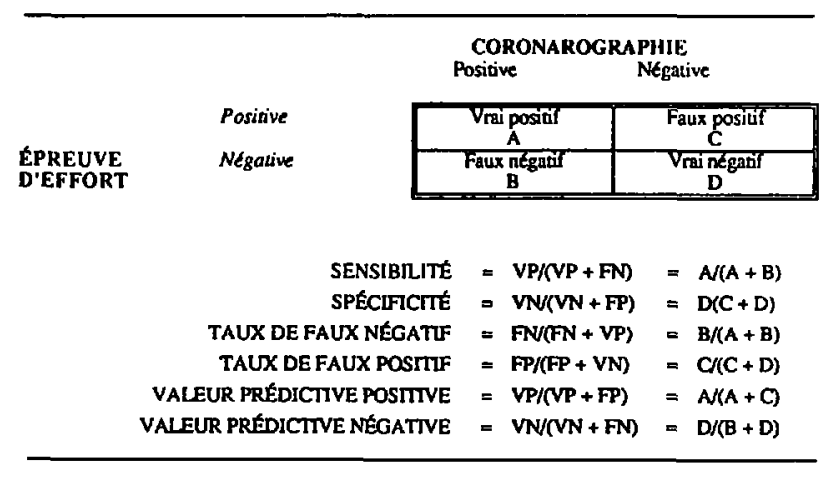

FIGURE 1 Exemple de tableau d'analyse de données diagnostiques.

gramme à 12 dérivations peut accentuer les trouvailles de l'histoire et de l'examen physique. Les changements du segment ST compatibles avec un vieil infarctus sont souvent suggestifs de maladie coronarienne. Les ondes $U$ positives à l'électro au repos sont associées à une maladie de la branche principale de la coronaire gauche. ${ }^{19}$

Une fois que l'on a obtenu les données susmentionnées, on peut exiger des épreuves diagnostiques supplémentaires pour pouvoir confirmer la présence ou l'absence de maladie coronarienne. Ces épreuves peuvent être accomplies : 1) au repos ou 2) pendant un exercice (Épreuve d'effort). C'est dans ce segment du travail diagnostique qu'il y a le moins de consensus dans la littérature. Lorsqu'on examine les données cardiodiagnostiques non-invasives, la terminologie suivante prend son importance si on veut bien comprendre les capacités diagnostiques d'une épreuve isolée : sensibilité et spécificité (lorsque comparées à un "étalon-or» tel que l'angiographie coronarienne) (Figure 1) ${ }^{20}$ Lorsque l'on connait les caractéristiques opérationnelles d'une épreuve, on peut estimer la probabilité de la maladie coronarienne chez un patient donné en utilisant le théorème de Bayes.

Le théorème de Bayes permet au clinicien de calculer, avant de demander une épreuve, la probabilité de la présence d'une maladie (e.g., maladie coronarienne) si l'épreuve diagnostique est positive. ${ }^{21}$ Pour calculer la probabilité post-test de la présence d'une maladie, nous devons connaître les choses suivantes :

1 la prévalence de la maladie dans un groupe de patients semblables aux patient évaluées;

2 la sensibilité et spécificité du test diagnostic.

Si la probabilité de maladie est faible, malgré une épreuve positive, il n'y a pas lieu de demander d'épreuves additionnelles. De façon inverse, s'il y a une probabilité importante de maladie avec une épreuve positive, il devient alors justifié de l'inclure dans le cheminement diagnostique.

Si l'évaluation diagnostique préliminaire n'a pas confirmé la présence de maladie coronarienne, la prochaine étape est l'épreuve d' effort. Un ECG d'effort augmente le travail du myocarde via un exercice progressif. Les indicateurs d'ischémie comprennent le développement de l'angine, des changements à l'ECG (e.g., une déviation du segment ST, l'apparition de dysrythmie, les troubles de conduction) et des anomalies hémodynamiques.' L'ECG d'effort a une valeur limitée comme moyen de dépistage dans une population asymptomatique. Finalement, les données tirées de cet examen doivent être considérées avec attention puisque la sensibilité et la spécificité seront différentes chez les hommes et chez les femmes.

L'épreuve d'effort peut aussi être accomplie en utilisant des marqueurs isotopiques. La scintigraphie à l'exercie est l'examen le plus approprié lorsqu'il y a des anomalies pré-existantes à l'ECG qui en limitent l'interprétation ou quand les résultats de l'épreuve d'effort à l'ECG sont ambigüs ou donnent des résultats inattendus. Autant le thallium 201 que le technecium 99 sont utilisés comme isotopes. ' Au repos, il faut une sténose importante des coronaires $(>90 \%)$ pour que l'on considère le test au thallium positif. Des défauts de perfusion apparaissent 30 à 60 minutes après l'injection de radio-isotopes. Il y a périodes de redistribution deux à quatre heures après l'injection. On répète la scintigraphie après quatre heures. Les déficits de remplissages à une et quatre heures signalent du tissu infarci. Les défauts de perfusion présents à une heure mais qui disparaissent après quatre heures (réversibles) indiquent la présence de zone d'ischémie du myocarde.

Même si l'épreuve au thallium peut être utilisée comme composante de ou à la place d'un ECG d'effort, on lui adjoint souvent l'injection de dipyridamole intraveineux. ${ }^{22}$ Le dipyridamole est un vasodilatateur coronarien et il est administré aux patients qui ne peuvent faire l'exercice sur tapis roulant à cause d'une maladie vasculaire périphérique. L'épreuve au thallium-dipyridamole (DPT) non seulement donne une information diagnostique importante mais aussi offre des capacités pronostiques importantes dans un sous-groupe choisi de patients chinurgicaux. ${ }^{23}$ Cependant, cette épreuve a une valeur limitée lorsqu'il y a maladie d'un seul vaisseau (coronaire gauche ou droite principle) ou une maladie proximale des trois vaisseaux. ${ }^{24}$ Des travaux plus récents suggèrent que des améliorations dans le protocole (répétition de l'injection de thallium) et les mesures quantitatives de redistribution vont augmenter la valeur prédictive de l'épreuve. ${ }^{25.26}$

Une autre forme d'épreuve d'effort est l'activité quotidienne. L'electrocardiogramme ambulatoire, par enregistrement de type Holter, permet la détection à l'électrocardiogramme d'épisodes ischémiques symptomatiques (angine) et ceux aussi qui sont silencieux (pas d'angine). ${ }^{27}$ 
Les tenants de cette technologie la croient plus utile que les épreuves diagnostiques courantes autant pour le diagnostic que pour l'évaluation du risque. ${ }^{28}$ Cependant, d'autres stipulent que l'ECG d'effort donne des informations semblables, plus facilement quantifiables, et que la seule indication pour l'utilisation de l'ECG ambulatoire est la détection d'épisodes de vasospasme coronarien. ${ }^{29}$ Un groupe de travail de l'Association Cardiaque Américaine a évalué cette technologie et mentionne qu'il faut plus de donnés avant de considérer que cette technique fera partie des méthodes diagnostiques de routine pour la maladie coronarienne. ${ }^{30}$

Plusieurs techniques d'imagerie, telles la scintigraphie nucléaire, l'échocardiographie et l'angiographie, pourront établir définitivement la présence de maladie coronarienne et aussi de documenter la qualité de la performance ventriculaire. Des revues récentes ont souligné l'importance de telles méthodes diagnostiques dans la période péri-opératoire. ${ }^{1,31}$ Des épreuves par scintigraphie peuvent évaluer la perfusion myocardique, ainsi que la viabilité et la fonction du ventricule. Même si l'échocardiographie est utile comme mode de surveillance intra-opératoire (e.g., échographie trans-cesophagienne), l'ultrasonographie devient elle aussi une composante importante du cheminement diagnostic en cardio-vasculaire. Cette forme d'épreuve devient adaptée aux épreuves d'efforts et permet le diagnostic de maladies valvulaires et congénitales cardiaques. Finalement, l'angiographie coronarienne sera la dernière étape dans l'arbre de décision qui permettra de définir la présence de maladie coronarienne.

On peut donc développer un algorithme qui permettra aux cliniciens de prescrire les épreuves cardio diagnostiques selon les étapes suggérées ci-haut (Figure 2).

\section{L'attribution du risque cardiaque dans la période pré-opératoire}

Après qu'un diagnostic cardio-vasculaire est établi, il devient utile de quantifier le risque d'un événement cardiaque morbide dans la période péri-opératoire. La définition du risque dépend de nombreux facteurs incluant les lésions cardiovasculaires. Eagle et Boucher suggèrent que certains sous-groupes de patients chez lesquels on prévoit un risque de plus de $15 \%$ d'incidents cardiovasculaires et péri-opératoires, devraient subir une évaluation plus extensive. Les sous-groupes qui montrent un taux de morbidité de moins de $5 \%$ n'ont pas besoin d'avoir une évaluation plus poussée. ${ }^{32}$

Les deux facteurs pré-opératoires qui semblent augmenter le risque de morbidité cardiaque post-opératoire sont l'infarctus du myocarde dans les derniers six mois et une insuffisance cardiaque congestive concomittante. ${ }^{1}$ Tous les autres facteurs pré-opératoires incluant l'âge,

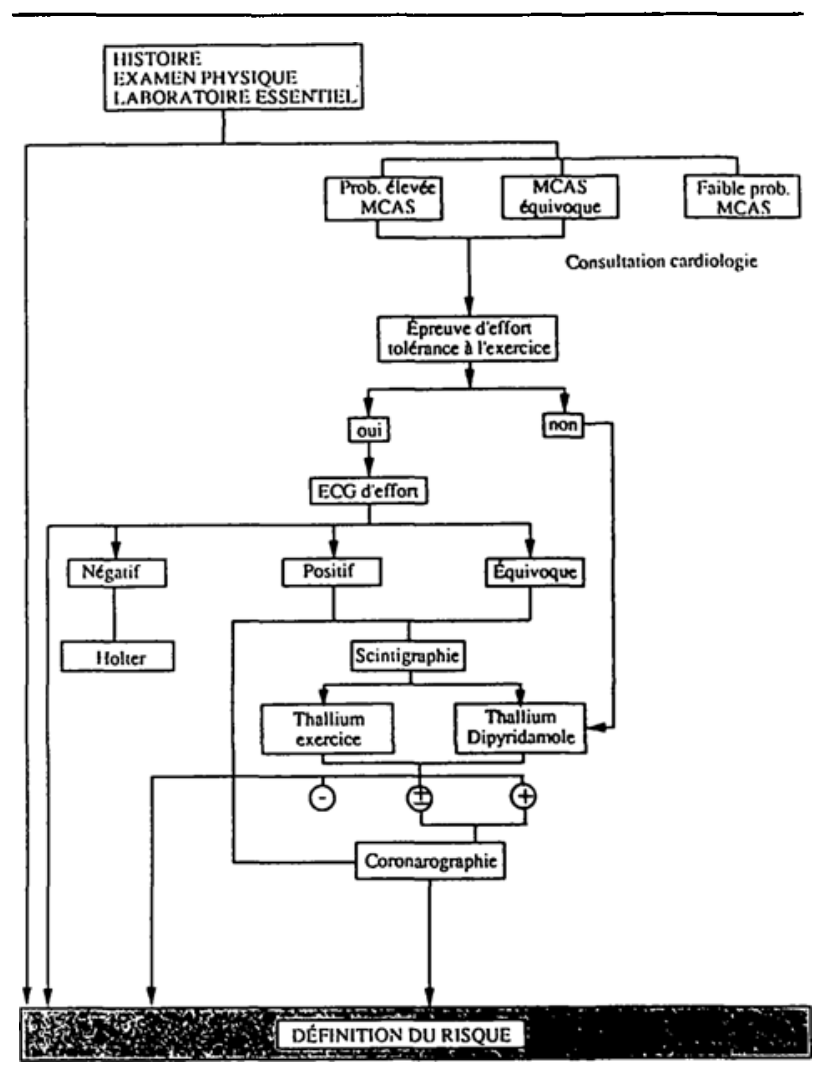

FIGURE 2 Algorithme d'utilisation des épreuves diagnostiques cardiaques. Traduit de : Barash PG (ed.) Clinical Anesthesia Update Series J.B. Lippincott Publisher, 1990.

l'angine, l'insuffisance cardiaque congestive antérieure, l'hypertension, le diabète, etc., peuvent avoir une importance chez certains sous-groupes de patients choisis. L'infarctus post-opératoire est une lésion porteuse d'un taux de mortalité de plus de 50\%. Dans l'Index de risque cardiaque, le facteur qui a la plus grande pondération est la présence d'un gallop en $\mathrm{S} 3$, habituellement associé à de l'insuffisance cardiaque congestive. ${ }^{33}$

Des travaux récents suggèrent que les patients avec ischémie pré-opératoire (silencieuse ou symptomatique) présentent un risque plus élevé de complications postopératoires. Dans une revue de patients soumis à la chirurgie vasculaire, $38 \%$ de ceux qui présentaient un épisode cardiaque post-opératoire avaient une ischémie pré-opératoire. ${ }^{34}$ Seulement $1 \%$ des patients sans ischémie pré-opératoire avaient présenté une morbidité cardiaque post-opératoire. Une étude pertinente faite chez les chiens montre que de brefs épisodes d'ischémie du myocarde, qui individuellement ne produisent pas de nécrose du myocarde, auraient cependant un effet cumulatif et produisent une zone nécrotique significative (infarctus). ${ }^{35}$ L'importance de ces trouvailles peut être rapprochée des constatations faites chez des patients soumis à 
des interventions vasculaires périphériques. L'infarctus du myocarde post-opératoire était en relation directe avec le nombre et la durée des épisodes ischémiques et la durée totale de l'ischémie. ${ }^{36}$

La prescription systématique d'épreuves diagnostiques non seulement augmente la sensibilité et la spécificité propre au diagnostic de maladie coronarienne, mais aussi améliore la stratification du risque ${ }^{37.38} \mathrm{La}$ discussion qui précède laisse apparâtre que les malades peuvent être divisés en trois classes de risque : faible, intermédiaire et élevé. Dans un groupe de patients $(n=200)$ soumis à une chirurgie vasculaire majeure, Eagle et al. décrivent un groupe à faible risque qui n'avait pas de signe ou symptôme clinique (e.g., angine, diabète, onde $Q$ à l'ECG, etc.) suggestif de maladie coronarienne. ${ }^{36}$ Seulement 3\% (2/64) ont subi un épisode d'ischémie post-operatoire. Par contre, $50 \%$ (10/20) des patients du groupe à haut risque (au moins trois facteurs de risque clinique), ont eu des épisodes de morbidité cardiaque post-opératoire cliniquement significatifs. Une majorité des patients $(n=116)$ démontraient une ou deux variables cliniques et ont été assignés à un groupe à risque intermédiaire. En se basant sur la présence ou l'absence de redistribution de thallium lors du test au thalliumdipyridamole, ce groupe a été subdivisé ensuite en groupes à faible $(n=64)$ et haut risque $(n=54)$. Seulement 3\% (2/64) des patients sans redistribution de thallium ont eu un événement cardiaque post-opératoire. Par contre, ceux chez lesquels on constatait la redistribution du thallium ont eu $30 \%$ (16/54) d'épisodes postopératoires cardiaques. Les auteurs concluent que la scintigraphie préopératoire au thallium-dipyridamole facilite la stratification des patients qui sont dans un groupe à risque intermédiaire, selon l'évaluation clinique. De plus, et ceci est probablement plus important, ils ont montré que près de la moitié des patients de leur série pouvaient être classés en groupes à faible et à haut risque uniquement à partir de l'information clinique et que chez ceux-ci la scintigraphie au thallium dipyridamole n'était pas utile.

\section{Surveillance post-opératoire de l'infarctus du myocarde}

L'infarctus du myocarde post-opératoire est un événement qui amène un mauvais pronostic ( $>50 \%$ de mortalité). Sur un plan théorique, la détection précoce et le début rapide d'une thérapie pourraient amener une diminution de ce taux de mortalité. Plusieurs protocoles ont été mis de l'avant pour établir la présence ou l'absence d'infarctus (ROMI). Ces protocoles s'étendent de l'admission à l'unité coronarienne avec surveillance extensive, et à l'autre extrême se limitent à l'observation sur les unités de soins. Charlson et al. ont évalué différentes stratégies de surveillance de l'infarctus pour les patients cardiaques qui sont asymptomatiques en post-opératoire. ${ }^{39} \mathrm{Ils}$ ont trouvé que l'obtention d'un électrocardiogramme le jour de la chirurgie et aux jours un et deux en post-opératoire permet d'identifier le nombre le plus important de patients qui vont éventuellement développer un infarctus. Leurs données suggèrent que les protocoles utilisés habituellement pour documenter les infarctus vont apparamment omettre $58 \%$ des patients qui ont subi un infarctus ou présenté de l'ischémie. Dans une étude rétrospective d'évaluation des patients asymptomatiques dans une unité de réanimation post-opératoire, $\mathrm{McCloskey} \mathrm{et} \mathrm{al}$. rapportent qu'à moins d'instabilité hémodynamique ou d'un besoin de thérapie anti-dysrythmique intra-veineuse, la surveillance pour l'infarctus peut très bien être effectuée dans les unités de soins. ${ }^{40}$ Des critères d'admission plus sévères dans les unités de soins coronariens pourront amener une diminution des coûts sans compromettre le devenir des patients.

\section{Résumé}

En résumé, la cuieillette d'une histoire clinique complète est une partie critique dans le diagnostic et la stratification du risque des patients avec maladie cardiaque qui vont subir une chirurgie non-cardiaque. Plusieurs des facteurs associés à la morbidité cardiaque péri-opératoire sont amenables à la thérapie, et un traitement agressif et précoce semble avoir des effets bénéfiques sur la morbidité et la mortalité. ${ }^{41}$

Cette revue est en partie basé sur: Barash PG: Preoperative Evaluation of the Cardiac Patient for Noncardiac Surgery. Clinical Anesthesia Updates. $1: 1-10,1990$.

\section{Références}

(Voir page $\mathrm{R} 138$ ) 